\title{
N-Terminal Fragment Brain Natriuretic Protein
}

National Cancer Institute

\section{Source}

National Cancer Institute. N-Terminal Fragment Brain Natriuretic Protein. NCI

Thesaurus. Code C88524.

$\mathrm{N}$-terminal fragment brain natriuretic protein $(76 \mathrm{aa}, \sim 9 \mathrm{kDa}$ ) is encoded by the human NPPB gene. This protein is a marker for cardiac failure. 